\title{
Enhanced tapetal-like reflex in sector retinitis pigmentosa
}

\author{
Shishir Verghese (ㄷ, George J Manayath, Ratnesh Ranjan, Venkatapathy Narendran
}

Retina \& Vitreous, Aravind Eye Hospital Coimbatore, Coimbatore, India

\section{Correspondence to} Dr Shishir Verghese: shishirverghese@gmail.com

Accepted 27 July 2021
Check for updates

(c) BMJ Publishing Group Limited 2021. No commercial re-use. See rights and permissions. Published by BMJ.

\begin{tabular}{l}
\hline To cite: Verghese $\mathrm{S}$, \\
Manayath GJ, Ranjan R, \\
et al. BMJ Case Rep \\
2021;14:e245190. \\
doi:10.1136/bcr-2021- \\
245190 \\
\hline
\end{tabular}

\section{DESCRIPTION}

A 55-year-old woman presented with complaints of decreased vision in the right eye (RE). Her best-corrected visual acuity in the RE was 20/30 and left eye was 20/20. Both eyes (BEs) anterior segment examination was unremarkable. There was no history of night blindness or decreased vision in any of the family members. Fundus examination revealed presence of retinal pigment epithelial (RPE) hypopigmentation and atrophy at the posterior pole along with an enhanced golden tapetal sheen seen in the mid-periphery in all quadrants with characteristic retinal vessel sparing (figure 1A,B). Fundus autofluorescence revealed an area of granular hypoautofluorescence along the inferior arcade with a crescent-shaped hyperautofluorescence in BEs (figure 1C,D).

Spectral domain optical coherence tomography (SD-OCT) revealed a lamellar macular hole in the RE and a normal foveal contour in the left eye with an absent photoreceptor layer temporal to the macula in BEs (figure 2A,B). Additional SD-OCT line scans superior to the macula near the superior arcade revealed an intact photoreceptor layer,
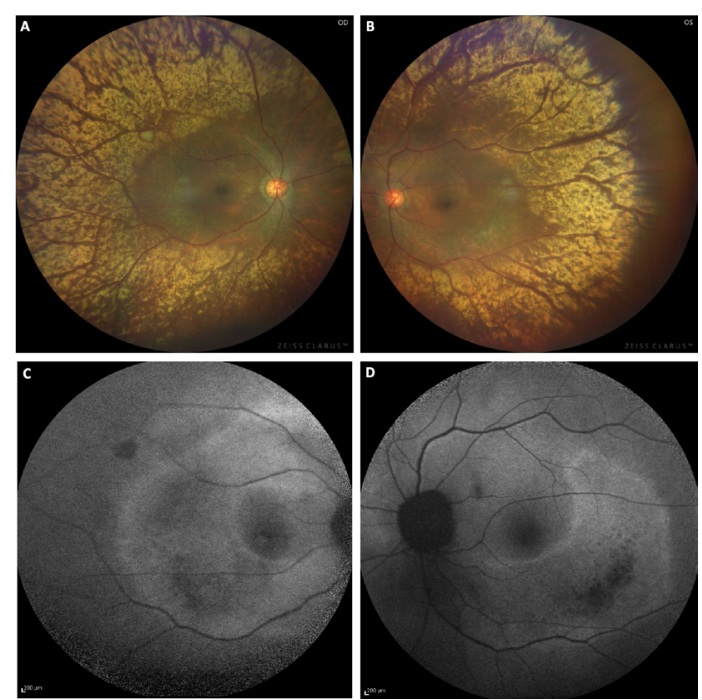

Figure 1 Colour fundus photo of both eyes (BEs) showing pigmentary changes along the inferior arcades and within posterior pole. Enhanced golden metallic sheen is seen starting from the inferior and superior arcades and involving the mid-periphery in BEs. Note the relative sparing of few areas near the peripheral retinal vasculature $(A, B)$. Fundus autofluorescence of BEs showed an area of granular hypoautofluorescence along the inferior arcade in BEs surrounded by a crescentshaped area of hyperautofluorescence $(C, D)$. whereas photoreceptor layer was absent inferior to macula near the inferior arcade (figure $2 \mathrm{C}-\mathrm{F}$ ). Based on the multimodal imaging findings, the patient was diagnosed with sector retinitis pigmentosa (RP) in BEs with lamellar macular hole in the RE. She was advised observation and a routine follow-up. Sector RP is an atypical form of RP in which only one or two fundus quadrants show clinical signs of the disease. ${ }^{1}$ In our patient, multimodal imaging features were suggestive of sector RP with photoreceptor layer loss in the area of RPE degeneration was seen on SD-OCT. Tapetal-like reflex (TLR) is an unusual, golden, bright scintillating, particulate reflection on indirect ophthalmoscopy relatively sparing the fovea similar to those seen in the eyes of some vertebrates. ${ }^{2}$ TLR has been described in female carriers of X-linked RP and was also seen in a healthy young male. ${ }^{3}$ Additionally, abnormal fundus reflections in male patients have been reported in Oguchi disease, X-linked retinoschisis, sheen retinal dystrophy and early X-linked RP. TLR has been reported to lie deep to the retinal blood vessels and at the level of the outer retina and RPE. ${ }^{3}$ It could be due to deposits, thickening or degeneration of the Bruch's membrane, retinal deposits or an alteration at the level of the RPE photoreceptor interface. ${ }^{3}$ We report the presence of an enhanced TLR located in the mid-periphery in a patient with sector RP which confirms its association with hereditary retinal degenerations; however, the nature and
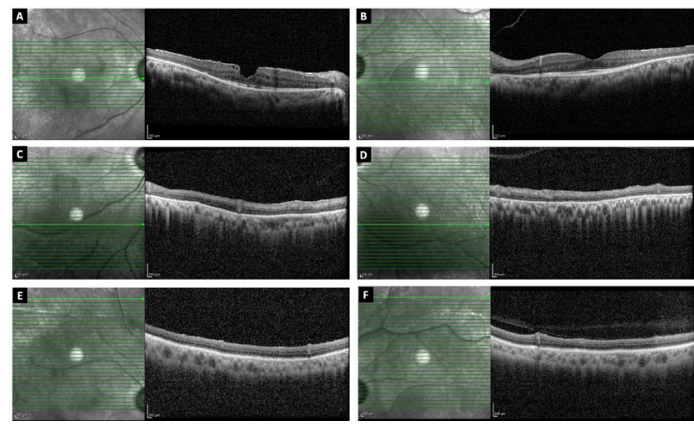

Figure 2 Spectral domain optical coherence tomography (SD-OCT) line scan of the right eye (RE) showing a lamellar macular hole with minimal intraretinal cystoid spaces (A). Line scan through the fovea in the left eye (LE) showing a normal foveal contour (B). Note the photoreceptor loss in both the scans temporal to the macula (A, B). SD-OCT line scan inferior to the macula (near the inferior arcade) in the $R E$ and $L E$, respectively, showing an absent photoreceptor layer (C, D). SD-OCT line scan superior to the macula (at the superior arcade) showing intact photoreceptor layer (E, F). 


\section{Learning points}

- Abnormal fundus reflections have been reported in a variety of heredomacular degenerations with the tapetal-like reflex (TLR) most commonly seen in carriers of $X$-linked retinitis pigmentosa (RP).

- TLR can also be seen in sector RP and use of multimodal imaging is important for documentation and disease progression.

origin of the phenomenon are still not clear and further studies will throw an insight into this unique finding.

Contributors SV: Concept and design, manuscript writing. GJM: Concept and design, editing and critical revision of manuscript. RR: Image and data acquisition, manuscript editing. VN: Concept and design, supervision.
Funding The authors have not declared a specific grant for this research from any funding agency in the public, commercial or not-for-profit sectors.

Competing interests None declared.

Patient consent for publication Obtained.

Provenance and peer review Not commissioned; externally peer reviewed.

\section{ORCID iD}

Shishir Verghese http://orcid.org/0000-0003-4295-8949

\section{REFERENCES}

1 Coussa RG, Basali D, Maeda A, et al. Sector retinitis pigmentosa: report of ten cases and a review of the literature. Mol Vis 2019;25:869-89.

2 Kalitzeos A, Samra R, Kasilian M, et al. Cellular imaging of the tapetal-like reflex in carriers of RPGR-associated retinopathy. Retina 2019;39:570-80.

3 Schatz P, Bregnhøj J, Arvidsson H, et al. A tapetal-like fundus reflex in a healthy male: evidence against a role in the pathophysiology of retinal degeneration? Mol Vis 2012:18:1147-55.

Copyright 2021 BMJ Publishing Group. All rights reserved. For permission to reuse any of this content visit

https://www.bmj.com/company/products-services/rights-and-licensing/permissions/

BMJ Case Report Fellows may re-use this article for personal use and teaching without any further permission.

Become a Fellow of BMJ Case Reports today and you can:

- Submit as many cases as you like

- Enjoy fast sympathetic peer review and rapid publication of accepted articles

- Access all the published articles

Re-use any of the published material for personal use and teaching without further permission

\section{Customer Service}

If you have any further queries about your subscription, please contact our customer services team on +44 (0) 2071111105 or via email at support@bmj.com.

Visit casereports.bmj.com for more articles like this and to become a Fellow 